\title{
Theoretical Research on Industry and Finance Combination of Domestic and Foreign Enterprise Group
}

\author{
Zhongzhi Wang \\ Development and Reform Commission of Sheyang \\ Sheyang 224300, China \\ E-mail:wzz75518@163.com \\ Lianghai Lei \\ Business School \\ University of Shanghai for Science and Technology \\ Shanghai 200093, China \\ E-mail: Leilh555@163.com
}

\begin{abstract}
This paper aims at systematically studying the industry and finance combination from a relatively micro aspect, namely the enterprise group. This paper takes the enterprise group as the subject in research. Based on the combination of industrial capitals and financial capitals, this paper analyzes the concepts, characteristics, and types of industry and finance combination in large enterprise groups that regard the industry as the main body. Besides, this paper makes a theoretical analysis of comparing the industry and finance combinations in domestic and foreign enterprise groups. By this research, the author hopes to discuss how large enterprise groups make best use of resources, economy of scale, and economy of scope and improve the core competitiveness by combining industrial capitals and financial capitals.
\end{abstract}

Keywords: Enterprise group, Industry and finance combination, Theoretical research

\section{Concepts for industry and finance combination in enterprise groups}

The enterprise group is a multi-level and multi-functional economic organization that is engaged in trans-national and diversified operation, formed by enterprises that want to extend the business operations, improve self competitiveness, and obtain necessary market shares, consisting of many legal subjects (may include enterprises, non-profit organizations, and social organizations), and taking the property right as the core.

For the sake of requirements for the research, this paper defines the industry and finance combination as: a mode combined by industrial sectors and financial sectors by certain economic ways organically, taking economic profits as the axis. Along with the changes of macro economic institution and financial system, the adjustment of social legal system, and the perfect of enterprise system, its connotations tend to be enriched, regulated, and developed. Therefore, the industry and finance combination is a dynamic historical concept.

The industry and finance combination is a product from commodity economy at certain stage. The separation of credit capitals from industrial capitals and commercial capitals, the separation of deposit subjects and investment subjects, and the mutual dependence of industrial sectors and financial sectors serve as the pre-conditions for the existence and development of industry and finance combination. From the history of industry and finance combination, it not only changes the constitution of industrial capitals, creating a new industry-finance relationship, but also reforms the appearance of social economy thoroughly, speeding up the transformation of social economy from "agricultural economy, to industrial economy, to financial economy". In the world, the industry and finance combination has already become a popular trend of modern market economy.

\section{Characteristics of the enterprise group in industry and finance combination}

The enterprise groups in industry and finance combination are different in form in developed countries. But in nature they have some similarities. The main characteristics are as follow:

Industry and finance integration. In an industry and finance combination, the financial capitals and industrial capitals are usually in interpenetration. Japan Toyota Motor Corporation, Sumitomo Mitsui Banking Corporation, and Tokai Bank are big stockholders mutually.

Giant scale. After the World War Two, six large enterprise groups (typical enterprise groups in industry and finance 
combination) come into being in Japan. They possess considerable child companies and affiliated companies in the world (Ming Huang, 2000, p31-32).

Diversified operation. Diversified operation is an effective way for enterprise groups in industry and finance combination free from risks. Sometimes the enterprise group in industry and finance combination is named after certain industry. However, its real operations cover more than one industry. For example, the products of American International Telephone and Telegraph Corporation are not only communication equipments but also services, foods, natural resources, finance and insurance, cosmetic, and medicine (Hangsheng Xie, 2000, p1-2).

Market internationalization. Due to the internationalization of domestic market and world market, the financial globalization and liberalization, enterprise groups have to operate in both domestic and world markets, making best use of domestic and world resources. Trans-national operations offer wide development spaces and valuable market chances for enterprise groups in industry and finance combination, which facilitate them to form stronger competitiveness in world market.

Industrial monopoly. The enterprise group in industry and finance combination is usually the combination of giant enterprises with strong economic power, which possess certain monopoly positions in one industry (Yan Fu, 2003, p1-2).

\section{The type of industry and finance combination by domestic and foreign enterprise groups}

Mutual penetration and integration of industrial capitals and financial capitals is one of important nature of modern enterprise group's diversified operation. In Japan there are six large enterprise groups. Bank of Mitsubishi, Mitsui Banking Corporation, Sumitomo Banking Corporation, Fuji Bank, Sanwa Bank, and Dai-Ichi Kangyo Bank are respectively the core enterprise of six enterprise groups. They impact other enterprises in the group by issuing loans and appointing managers. In fact, they control almost all stocks of one group. Chase Manhattan Bank is the financial support of Rockefeller Financial Group. Citibank is the main enterprise in Citicorp. Ford Credit Corporation is the main child company of Ford Motor Corporation.

\subsection{The classification according to the way of industry and finance combination}

(1) Financial capitals penetrate into an industry. The penetration of financial capitals into the industry starts from late $19^{\text {th }}$ century. Usually, the banking capitalists can control industrial capitals by means of financial institutions, the omnipotent monopoly. The two penetrate into each other and integrate together. Two ways can help to control industrial capitals. Firstly, financial institutions directly buy industrial company's stocks. At present, many financial institutions, such as foreign commercial banks' trust departments, and China Life Insurance Company, hold amounts of large enterprises' stocks. Secondly, financial institutions, mainly investment banks, can control an industrial company by monopolizing the sale of its securities or serving as the intermediary of stock transaction. The typical instances are Morgan Financial Group before the World War II and the California Financial Group after the War.

(2) Industrial capitals penetrate into finance. The profit rate of finance industry is above the average of industrial and commercial industry, which serves as a law of attracting financial groups into financial industry. Rockefeller Financial Group is based on industrial capitals and banking monopoly capitals. According to the degree of penetration, this mode includes two types. Firstly, the enterprise group takes the finance as the backbone industry, starting from industrial capitals, and accumulating capitals by continuously expanding the production. In operating industrial capitals, the enterprise group invests some capitals into finance industry, forming a giant financial core. Finally, the financial core can control a series of industrial and commercial enterprises, forming a monopoly financial group. A typical example is Japan's Mitsubishi Financial Group. Secondly, the finance sector is not the backbone of the enterprise group. In expanding the production, the finance sector monopolizes a batch of important industrial sectors for a long period. Due to the diversified operation, the enterprise group also invests in the finance industry. The typical example is DuPont Financial Group.

\subsection{The classification according to the concerned financial fields}

(1) Operate commercial banking business. At present Rockefeller Financial Group holds several commercial banks, including Chase Manhattan Bank, Chemical Bank, and New York Bank. Chase Manhattan Bank is core and the main financial support for Rockefeller Financial Group. Based on rich capitals from commercial banks, Rockefeller Financial Group invests in aircraft, telecommunication, and chemical fields widely. Its economic power grows fast and surpasses Morgan Financial Group. For a long period, Rockefeller Financial Group is always the No.1 monopoly financial group in USA.

(2) Operate insurance business. On one hand, by operating insurance business, financial group can get considerable and stable capitals. On the other hand, along with the enlarging scale and increasing investments, self operated insurance can disperse risks and avoid expense for insurance. Therefore, different insurance companies become important members in the financial group. 
(3) Operate securities business. Foreign large financial groups usually hold one or more security companies, by which they can issue securities of industrial companies. Then, a series of companies will be under the control of the financial group. Morgan Stanley is always the important investment bank that controls amounts of industrial companies for Morgan Financial Group.

(4) Operate credit business. Although to operate commercial banking business is restricted in many aspects, to start credit business can also generate considerable capitals for one financial group. Therefore, some financial groups that are engaged in amounts of retailers usually invest in credit business.

\subsection{The classification according to the combination of industry and finance}

(1) Set up financial institutions directly. Financial groups usually set up banks, insurance companies, and securities companies directly according to the law. This kind of financial institutions can be formed independently. In fact, they are based on a financial group's certain functional department, such as the trust department or the banking department. By this way, the financial group can control the financial institutions effectively. However, if a financial group is unfamiliar with financial business, it will be hard for it setting up financial institutions directly. In addition, many countries regulate strict requirements for enterprises setting up financial institutions.

(2) Hold stocks of present financial institutions. By buying financial institutions' stocks directly, financial groups can control commercial banks and other financial institutions, and by which control other companies. By this way, financial groups can invest in present financial institutions according to self powers. They can focus on their own business. Beside, they can increase or decrease investments based on own development strategies and practical conditions. However, this method can not realize an effective control over financial institutions. All large financial groups compete for influential financial institutions. They have to spend tremendous capitals in controlling financial institutions.

(3) Appoint managers. By appointing managers, financial groups can control banks by enterprises, and then control enterprises by banks, forming a multi-level penetration of personnel.

(4) Credit relation. Along with the enlarging scale of enterprise, the proportion of self capitals to total capitals tends to decrease. The external capitals are mainly from some big banks, forming so-called "series loans". Then, it forms big banks-centered financial groups (Wenguang Zhao, 2004).

\section{The comparison of China and foreign enterprise groups' industry and finance combination}

Among the modes discussed above, some enterprise groups may choose different modes in dealing with different financial enterprises or different financial fields. All the modes have different advantages and disadvantages. They set up different requirements for enterprise groups. So, enterprise groups can not adopt all modes. With fixed goals, enterprise groups should select the most proper mode to operate financial business. The selection is affected by two aspects. The first is the strengths of the enterprise group. The second is the strict supervision system regulated by the government on financial industry, especially the strict market entrance standard.

Although enterprise group's financial company operates only more than one decade, it gains a wide acceptance from enterprise groups because it can help to save financial costs and internal transaction costs, and improve the use efficiency of capitals. Presently, to form a financial company can benefit the enterprise group to a great degree and has minimum risks. According to the spirits of Administration of the Finance Companies of Enterprises Groups Procedures issued recently, the most important condition for enterprise groups applying for setting up finance companies is the correct positioning of finance companies, enterprise groups' scales and strengths, and business situations. First of all, finance companies are special financial companies that serve members in enterprise groups. They can not offer financial services for others. Therefore, if an enterprise group hopes to start wider financial businesses, it is not the best choice. Secondly, although the new procedure regulates lower market entrance standards than ever, it still sets up higher requirements for enterprise groups' business scales, credits, and operations (include industrial development and the cash flow). If an enterprise group fails to reach relevant standards, it can not adopt the mode. Furthermore, according to the latest requirements, except the enterprise group that is approval by China Banking Regulatory Commission, all finance companies must associate with foreign investors with rich specialized experiences. In other words, to set up a new finance company must introduce a qualified foreign investor. As a result, the enterprise group has to seek for a proper foreign partner in order to set up a finance company.

As investing in external financial companies, the simplest way is to buy stocks. In this mode, enterprise groups face fewer restrictions. By associating with partners that have complementary resources or same wish for operating financial business, enterprises can set up financial companies by cooperation. That is a better way for enterprise group realizing industry and finance combination. At present, with policy permission, enterprise groups can set up financial enterprises, such as trust companies, security companies, and insurance companies, by buying in stocks. Besides, enterprise groups can start funds management companies indirectly by trust companies or security companies. As for forming commercial banks, enterprise groups must get stricter examination and approval. Because financial regulation imposes stricter management on industrial capitals controlling financial companies, in order to escape from policy restriction, this mode 
is widely adopted by powerful enterprise groups that tend to invest more in financial industry. Although this mode means more difficulties in operation, it realizes an essential control over financial companies. However, on the other hand, it adds more difficulties and complexity to regulation.

Presently, some enterprise groups have already possessed the base for becoming the financial holding enterprise after years of operating in financial fields. Many professionals in financial industry agree that the most appropriate for practicing financial holding is not the industrial group but financial institution. As a matter of fact, this mode does not only require that the enterprise group realizes the holding of several financial companies but more important, the enterprise group can support the right operation and development of these financial companies. Therefore, the enterprise group should possess rich capitals and be capable of integrating financial resources and controlling risks. Then, it can achieve the coordinative development of industrial sectors and financial sectors in the group. Today, due to the poor experiences in financial industry and the short of professional experts, China's domestic enterprise groups could not reach the goal. Therefore, as for this kind of enterprise groups, the practical way is to accumulate experiences and capitals, and cultivate highly-qualified professional talents by practicing and developing in some financial fields, building up bases for the future. Meanwhile, in the financial regulation and supervision aspect, considering the control of risks, the regulation department sets up strict controls over enterprise groups executing the holding on several financial companies.

\section{References}

Chen, Yanling. (2005). The risks of integration of industry with finance and the preventive measures. Productivity Research. No.5.

Fu, Yan. (2003). The Way for Combination of Industry and Finance ------ Research on the Effectiveness of China's Industry and Finance Combination. Beijing: People's Publishing House. p1-2.

Gabriel Hawawini \& Claude Viallet. (2001). Finance for Executives: Managing for Value Creation, (2nd Edition).

Gerry Johnson \& Kevan Scholes. (2002). Exploring Corporate Strategy, Sixth Edition.

$\mathrm{Gu}$, Xiaomin \& Zhu, Junyong. (2005). The development of China's financial groups and the supervision measure. Shanghai Finance. No.3.

Huang, Ming. (2000). Modern Theory of Combination of Industry and Finance. Beijing: China Economy Publishing House. p31-33.

Li, Gesen. (2004). Evaluation of effectiveness of integration of industry with capital market: proofs from securities market. China Opening Herald. No.2.

Xie, Hangsheng. (2000). Research on Combination of Industry and Finance. Beijing: China Finance Publishing House. p1-2.

Xu, Tianxin. (2003). An analysis of the economic effect in the integration of industrial capital and financial capital in China. Financial Theory and Practice. No.8.

Zhao, Wenguang. (2004). Combination of Corporate Group and Finance: Theory and Practice. Beijing: Economic Management Publishing House. 